\title{
ANALISIS EFISIENSI SALURAN PEMASARAN IKAN TONGKOL HASIL TANGKAPAN NELAYAN DI DESA SERAYA TIMUR KECAMATAN KARANGASEM
}

\author{
Ni Kadek Nuriati \\ Jurusan Pendidikan Ekonomi, Fakultas Ekonomi \\ Universitas Pendidikan Ganesha Singaraja, \\ Indonesia
}

Email: kadeknuriati1000gmail.com

\begin{abstract}
Abstrak
Penelitian ini bertujuan untuk mengetahui pola saluran pemasaran ikan tongkol di Desa Seraya Timur Tahun 2017, jumlah marjin dan farmer share dari masing-masing pola saluran pemasaran ikan tongkol di Desa Seraya Timur Tahun 2017, dan pola saluran yang paling efisien dalam pemasaran ikan tongkol di Desa seraya Timur Tahun 2017. Penelitian ini merupakan jenis penelitian deskriptif kuantitatif. Data yang digunakan berupa data kualitatif dan data kuantitatif, sedangkan berdasarkan sumbernya data primer dan data sekunder. Data dikumpulkan dengan metode wawancara dan dokumentasi selanjutnya dianalisis dengan teknik analisis deskriptif dengan pendekatan kuantitatif. Hasil penelitian menunjukkan bahwa terdapat tiga pola saluran pemasaran ikan tongkol di Desa Seraya Timur Tahun 2017 yaitu, pola saluran pertama dari nelayan ke pedagang pengecer kemudian konsumen, kedua dari nelayan ke pedagang pengumpul ke pedagang pengecer kemudian konsumen, dan ketiga dari nelayan ke pedagang pengumpul kemudian pedagang besar (luar daerah). Pola saluran pemasaran I jumlah marjin sebesar Rp 5.000,00/kg dan farmer share $75,00 \%$, pola saluran II memiliki jumlah marjin sebesar Rp 11.000/kg dan farmer share sebesar $57,69 \%$, pola saluran III memiliki jumlah marjin sebesar Rp $8.000 / \mathrm{kg}$ dan untuk farmer share sebesar $65,21 \%$. Pola saluran I lebih efisien karena memiliki persentase paling kecil yaitu sebesar $2,50 \%$, dibandingkan saluran lainnya yaitu saluran II sebesar $6,53 \%$ dan $1,92 \%$, dan saluran III sebesar $9,56 \%$.
\end{abstract}

Kata Kunci : Farmer Share, Marjin, Saluran Pemasaran

\begin{abstract}
The aim of this study to know the pattern of marketing channel of tuna fish in Seraya Timur Village in 2017, the amount of margin and farmer share from each pattern of tuna fish marketing channel in Seraya Timur Village in 2017 and the most efficient channel pattern in the marketing of tuna in Desa while the East in 2017. The kind of this study was quantitative descriptive. This study used qualitative research and quantitative research based on primary data sources and secondary data. Data was collected by interview and documentation then analyzed by descriptive analysis technique with quantitative approach. The results showed that there are three patterns of marketing channels of tuna fish in Seraya Timur Village in 2017, namely the first channel pattern from fisherman to retailer and than consumer, second from fisherman to collecting merchant to retailer and than consumer, and third from fisherman to collecting merchant and than merchant (outside area). The amount of margin in marketing channel pattern I Rp $5.000 / \mathrm{kg}$ and farmer share $75.00 \%$, the amount of margin in marketing channel pattern II Rp $11.000 / \mathrm{kg}$ and farmer share of $57.69 \%$, The amount of margin in marketing channel pattern III Rp $8.000 / \mathrm{kg}$ and for farmer share of $65.21 \%$. The channel pattern I was more efficient because it had the smallest percentage $2.50 \%$ that was compared to other channels, namely channel II of $6.53 \%$ and $1.92 \%$, and channel III of $9.56 \%$.
\end{abstract}

Keywords : Farmer Share, Margin,marketing channel 


\section{PENDAHULUAN}

Pembangunan sektor perikanan adalah suatu proses perubahan dan pembaharuan yang berencana menuju tatanan masyarakat, khususnya masyarakat perikanan yang lebih baik. Perikanan mempunyai peranan yang cukup penting, terutama dikaitkan dengan upaya meningkatkan kualitas dan kuantitas produk perikanan, menghasilkan protein hewani dalam rangka memenuhi kebutuhan pangan dan gizi, meningkatkan ekspor, menyediakan bahan baku industri, memperluas lapangan dan kesempatan berusaha, serta mendukung pembangunan wilayah dan tetap memperhatikan kelestarian dan fungsi lingkungan hidup. Pertumbuhan sektor perikanan dan kelautan berasal dari produksi perikanan tangkap maupun maupun perikanan pembudidaya. Selama ini kegiatan produski perikanan tangkap lebih banyak dilakukan oleh petani (nelayan) kecil yang belum mempunyai akses terhadap manajemen usaha, modal, dan pemasaran.

Manajemen usaha merupakan faktor yang sangat penting dalam suatu perusahaan, dimana bisa membuat seseorang mengalami kegagalan dalam berwirausaha karena tidak memiliki pengalaman dalam manajemen usaha (Manullang, 2005). Dalam manajemen usaha pedagang dibidang penjualan kebutuhan sehari-hari menjadi objek yang menarik dimana usaha kecil menjadi alternatif pilihan banyak pihak yang ingin membuka lapangan kerja sendiri. Karena dalam menjalankan usaha akan memudahkan pedagang untuk menjalankan usaha akan memudahkan pedagang untuk menjalankan usaha, dan kebutuhan modal yang diperlukan relatif sedikit.

Modal merupakan sarana atau bekal untuk melaksanakan usaha (Gilarso, 2009). Menurut Amirullah dan Haris (2005), modal dalam pengertian ini dapat diinterprestasikan sebagai sejumlah uang yang digunakan dalam menjalankan kegiatan-kegiatan usaha, yang menjadi persoalan di sini bukanlah penting tidaknya modal, karena keberadaanya memang sangat diperlukan, akan tetapi bagaimana mengelola modal secara optimal sehingga usaha yang dijalankan dapat berjalan lancar. Dalam keterbatasan modal, usaha akan sulit untuk mengakses pasar, kesulitan akses pasar ini terjadi karena kurangnya keahlian dalam bidang pemasaran. Pemasaran adalah suatu proses sosial dan manajerial yang membuat individu dan kelompok memperoleh apa yang mereka butuhkan dan inginkan lewat penciptaan dan pertukaran timbal balik produk dan nilai dengan orang lain (Kotler dan Amstrong, 2001). Menurut Gitosudarmo, (2008), pemasaran dapat diartikan sebagai suatu kegiatan yang mengusahakan agar produk yang dipasarkannya itu dapat diterima dan disenangi oleh pasar.

Menurut Swastha (2002), pemasaran merupakan suatu interaksi yang berusaha untuk menciptakan hubungan pertukaran, tetapi pemasaran bukanlah merupakan suatu cara yang sederhana sekedar untuk menghasilkan penjualan saja. Jadi dapat disimpulkan bahwa pemasaran adalah suatu proses sosial dan menejerial yang berusaha untuk menciptakan hubungan pertukaran sehingga membuat individu dan kelompok memperoleh apa yang mereka butuhkan dan inginkan.

Pemasaran merupakan hal yang paling penting dalam menjalankan sebuah usaha perikanan. Kemampuan dalam memasarkan barang yang dihasilkan akan dapat menambah asset dalam upaya meningkatkan dan mengembangkan usaha. Pemasaran hasil produksi suatu usaha dalam memperoleh keuntungan yang maksimal akan tergantung pada pola dan saluran pemasaran. Sebuah usaha yang produktivitasnya bagus akan gagal jika pemasarannya tidak baik. Salah satu aspek pemasaran yang perlu diperhatikan dalam upaya meningkatkan arus barang dari produsen ke konsumen adalah efisiensi pemasaran, karena melalui efisiensi pemasaran selain terlihat perbedaan harga yang diterima nelayan sampai barang tersebut dibayar oleh konsumen akhir, juga kelayakan pendapatan yang diterima nelayan maupun lembaga yang terlibat dalam aktivitas pemasaran.

Pemasaran dianggap efisien apabila memenuhi dua syarat yaitu mampu menyampaikan hasil-hasil produsen kepada konsumen dengan semurah-murahnya, dan mampu mengadakan pembagian yang adil dari keseluruhan harga yang dibayar konsumen terakhir kepada semua pihak yang ikut serta didalam kegiatan produksi dan tataniaga barang itu (Mubyarto, 2002). 
Tingkat produktivitas sistem pemasaran dapat dilihat dari efisiensi dan efektifitas seluruh kegiatan fungsional pemasaran, yang juga menentukan kinerja operasi dan proses sistem. Kegiatan pemasaran perikanan tidak hanya proses pemindahan produk dari tangan nelayan selaku produsen ke tangan konsumen. Kegiatan pemasaran merupakan kegiatan yang sangat kompleks meliputi proses pengumpulan produk dari para nelayan, dan pendistribusian termasuk didalamnya pemilihan saluran pemasaran. Kegiatankegiatan tersebut bukan tanpa biaya. Efisiensi pemasaran dapat dinilai dari biaya akumulasi semua proses tersebut. sistem pemasaran akan semakin efisien apabila semua kegiatan tersebut dilakukan dengan mengeluarkan biaya minimum. Sistem pemasaran yang efisien akan mendorong rendahnya marjin pemasaran sehingga perbaikan pendapatan dipihak produsen, harga yang relatif murah bagi konsumen serta keuntungan yang normal bagi para pelaku kegiatan pemasaran akan tercapai.

Desa Seraya Timur terletak dikawasan timur Pulau Bali, Kabupaten Karangasem. Secara geografis Desa Seraya Timur terletak dipesisir pantai yang lautnya memiliki beragam biota laut dan memiliki sumber daya ikan yang melimpah. Dengan kekayaan laut yang melimpah tersebut makar, mayoritas pencaharian utama masyarakat Desa Seraya Timur adalah sebagai nelayan. Data menunjukkan profesi masyarakat di Desa Seraya Timur sebagai nelayan sebanyak $60 \%$ dan sebagai peternak atau petani sebanyak $40 \%$.

Dari 1540 KK yang tersebar diwilayah Desa Seraya Timur sebanyak 924 KK nelayan dengan rata rata hasil tangkapan tiap tahun 1663 ton (data tahun 2016). Sebagai nelayan, produksi utamanya yaitu ikan tongkol, sehingga daerah ini menjadi salah satu penghasil ikan tongkol di wilayah Karangasem. Ikan jenis ini memiliki daya tarik yang sangat tinggi baik lokal maupun ekspor tingginya produksi ikan hasil tangkapan tersebut perlu didukung oleh pemasaran yang baik.

Kegiatan pemasaran akan berjalan dengan baik dan lancar apabila didukung oleh daya beli konsumen yang tinggi dan juga kegiatan distribusi yang tepat. Namun sejauh ini saluran pemasaran ikan tongkol di
Desa Seraya Timur masih belum efisien, karena kegiatan saluran pemasaran tidak dilakukan oleh satu tangan tetapi dilakukan oleh beberapa perantara, baik skala besar maupun sekala kecil, sehingga membentuk mata rantai yang panjang.

Mata rantai yang panjang akan mengakibatkan biaya pemasaran menjadi tinggi, karena tiap perantara ingin mendapatkan keuntungan untuk menutup biaya pemasaran yang telah dikeluarkan. Besarnya keuntungan pemasaran dan biaya pemasaran ditingkat perantara merupakan komponen dalam pembentukan harga akhir (harga eceran) ditingkat konsumen. Hal ini akan berpengaruh pada harga di tingkat produsen, bahkan dapat menekan harga di tingkat produsen karena daya beli sebagian konsumen masih terbatas.

Aspek struktural lain adalah lemahnya posisi nelayan dalam pemasaran, yaitu nelayan tidak memiliki akses terhadap pasar. Kelemahan posisi tersebut menyebabkan marjin keuntungan pemasaran lebih banyak jatuh ke pedagang dan bukan ke nelayan ataupun pembudidaya ikan. Hal ini akan berpengaruh pada harga ditingkat produsen, bahkan dapat menekan harga ditingkat produsen karena karena daya beli sebagian konsumen masih terbatas. Selain itu, pola pemasaran ikan tongkol di Desa Seraya Timur berawal dari nelayan ke pedagang pengumpul ke pedagang pengecer kemudian konsumen. Panjang saluran pemasaran yang harus dilalui, mengakibatkan pemasaran ikan menjadi kurang efsien. Menurut Daniel (2002), semakin pendek rantai pemasaran suatu barang, maka terjadi biaya tataniaga semakin rendah, marjin tataniaga juga semakin rendah, harga yang harus dibayarkan konsumen semakin rendah, dan harga yang diterima produsen semakin tinggi.

Tujuan analisis marjin pemasaran adalah untuk melihat efisiensi pemasaran yang diindikasikan oleh besarnya keuntungan yang diterima oleh masingmasing pelaku pemasaran. Semakin tinggi proposi harga yang diterima produsen, semakin tinggi efisiensi sistem pemasaran tersebut. Besarnya keuntungan yang diterima oleh masing-masing pelaku pemasaran relatif terhadap harga yang dibayarkan konsumen atau relatif terhadap 
p-ISSN : 2599-1418

e-ISSN : 2599-1426
Jurnal Pendidikan Ekonomi Undiksha

Volume 10 No. 2 Tahun 2018 biaya pemasaran terkait dengan peran yang dilakukan oleh masing-masing pelaku. Apabila semakin besar marjin pemasaran ini akan menyebabkan harga yang diterima produsen semakin kecil dan mengindikasikan sebagai sistem pemasaran yang tidak efisien. Lebih jelasnya mengenai marjin pemasaran, dapat dilihat pada tabel 1 .

Tabel 1. Marjin Pemasaran dan Farmer Share yang diterima nelayan pada hasil tangkapan ikan tongkol di Desa Seraya Timur Tahun 2017.

\begin{tabular}{rlr} 
No & \multicolumn{1}{c}{$\begin{array}{l}\text { Lembaga Pemasaran } \\
\text { I }\end{array}$} & \multicolumn{1}{c}{$\begin{array}{l}\text { Harga } \\
\text { (rp/kg) }\end{array}$} \\
II $\quad$ Helayan & 15.000 \\
& Pedagang pengumpul & \\
& Harga beli & 15.000 \\
& Biaya timbang & 100 \\
& Biaya keranjang & 500 \\
& Biaya transportasi & 500 \\
& Keuntungan & 3.900 \\
& Harga jual & 20.000 \\
III & \\
& Hedagang pengecer & 20.000 \\
& Transa beli & 500 \\
& Keuntungan & 5.000 \\
& Harga jual & 25.500 \\
& Marjin Pemasaran & 10.500
\end{tabular}

Berdasarkan tabel 1, terlihat bahwa marjin pemasaran yang terjadi antar nelayan dan pedagang pengecer cukup besar yaitu $\mathrm{Rp} 10.500 / \mathrm{kg}$ ikan tongkol. Hal ini terjadi karena panjangnya saluran pemasaran yang dilalui untuk sampai pada konsumen akhir. Bagian keuntungan yang diterima oleh masing-masing lembaga pemasaran cukup bervariasi, untuk bagian harga, nelayan hanya menerima bagian sebesar $0,75 \%$. Berdasarkan data tersebut, bahwa pola pemasaran ikan tongkol di Desa Seraya Timur masih belum efisien karena saluran pemasaran yang panjang, dan belum mampu mengadakan pembagian yang secara adil dari keseluruhan harga yang dibayar oleh konsumen terakhir kepada semua pihak yang ikut serta dalam kegiatan produksi dan tataniaga barang itu.

Dari permasalahan tersebut, menarik keinginan peneliti untuk melakukan sebuah penelitian dengan judul Analisis Efsiensi Saluran Pemasaran Ikan Tongkol Hasil Tangkapan Nelayan di Desa Seraya Timur Kecamatan Karangasemn Tahun 2017. Tujuan penelitian ini adalah untuk mengetahui pola saluran pemasaran ikan tongkol hasil tangkapan nelayan di Desa Seraya Timur Tahun 2017, jumlah marjin dan bagian harga yang diterima produsen (farmer share) dari masing-masing pola saluran pemasaran ikan tongkol hasil tangkapan nelayandi Desa Seraya Timur Tahun 2017 dan saluran yang paling efisien dalam pemasaran ikan tongkol hasil tangkapan nelayan di Desa Seraya Timur Tahun 2017.

\section{METODE}

Penelitian ini termasuk jenis penelitian deskriptif. Penelitian deskriptif merupakan metode penelitian yang berusaha menggambarkan dan menginterprestasi objek sesuai dengan apa adanya (Sukardi, 2008:57). Dalam penelitian ini, akan dibahas mengenai pola saluran pemasaran dan tingkat efisisensi saluran pemasaran ikan tongkol. Data akan dianalisis secara deskriptif yang berupa pemaparan dan juga analisis kuantitatif yang berupa perhitungan. Untuk mengetahui pola saluran pemasaran Ikan tongkol dan marjin pemasaran digunakan analisis saluran pemasaran, sedangkan untuk mengetahui bagian harga yang diterima produsen digunakan analisis farmer share. Definisi operasional dalam penelitian ini adalah Nelayan, Pemasaran, Saluran pemasaran, Efisiensi pemasaran, Marjin pemasaran, Farmer share. Penelitian ini dilakukan di Desa Seraya Timur Kecamatan Karangasem. Subjek penelitian 
ini adalah nelayan, pedagang pengumpul dan pedagang pengecer (pedagang perantara) yang ada di Desa Seraya Timur selama bulan Februari - Mei 2017 yang berjumlah 31 orang. (26 orang nelayan, 3 orang pedagang pengumpul, dan 2 orang pedagang pengecer).

Objek dari penelitian ini adalah saluran pemasaran ikan tongkol untuk mengetahui pola pemasaran dan untuk mengetahui tingkat efisiensi dari saluran pemasaran ikan tongkol hasil tangkapan nelayan di Desa Seraya Timur yang dinilai dari margin pemasaran dan farmer share yang diperoleh melalui proses nelayan, pedagang pengumpul dan pedagang pengecer.

Jenis dan Sumber Data dalam penelitian ini adalah data kualitatif dan data kuantitatif. Data kualitatif dalam penelitian ini adalah data mengenai saluran-saluran pemasaran ikan tongkol yang dilakukan oleh nelayan dan para pedagang yang diperoleh dari hasil wawancara. Data kuantitatif dalam penelitian ini adalah data mengenai harga ikan tongkol, biaya-biaya yang dikeluarkan dalam pemasaran ikan tongkol, besarnya keuntungan yang ditetapkan perantara dan jumlah nelayan. Sedangkan sumber data yang digunakan dalam penelitian ini adalah data primer dan data sekunder. Data primer dalam penelitian ini berupa data langsung dari observasi lokasi penelitian yang berupa saluran pemasaran ikan tongkol, harga ikan tongkol, biaya pemasaran serta keuntungan yang ditetapkan para pedagang perantara. Data sekunder dalam penelitian ini berupa data yang diperoleh dari ketua kelompok nelayan di Desa Seraya Timur mengenai jumlah nelayan.

Metode pengumpulan data yang digunakan dalam penelitian ini adalah wawancara dan dokumentasi. Wawancara ditujukan kepada nelayan untuk mengetahui bagaimana pola saluran pemasaran yang dilakukan oleh nelayan yang ditujukan kepada pedagang pengumpul dan pedagang pengecer. Melalui wawancara ini, peneliti akan memperoleh data mengenai harga beli ikan tongkol di tingkat nelayan, biaya-biaya yang dikeluarkan, keuntungan yang diinginkan dari saluran pemasaran ikan tongkol, serta harga jual ikan tongkol ditingkat nelayan yang ditujukan kepada pedagang pengumpul dan pedagang pengecer. Dokumentasi dipergunakan sebagai pelengkap untuk memperoleh data mengenai jumlah anggota kelompok nelayan.

Instrumen penelitian yang digunakan dalam penelitian ini adalah pedoman wawancara terstruktur dan dokumentasi. Pedoman wawancara mengenai isian tanya jawab langsung dengan nelayan serta para pedagang perantara untuk mengetahui pola saluran pemasaran ikan tongkol, biaya yang dikeluarkan serta keuntungan yang diinginkan para pedagang perantara. Dokumentasi adalah pencatatan terhadap dokumen-dokumen yang berhubungan dengan penelitian yang dilakukan seperti data tentang jumlah anggota kelompok nelayan. Metode Analisis Data dalam penelitian ini, data yang digunakan berupa data deskriptif dan kuantitatif. Analisis deskriptif digunakan untuk menggambarkan pola saluran pemasaran ikan tongkol, sedangkan analisis kuantitatif digunakan untuk mengetahui efisiensi saluran pemasaran ikan tongkol. Metode analisis data yang digunakan adalah analisis pemasaran dan analisis farmer share.

Dalam analisis pemasaran mengenai saluran pemasaran dan marjin pemasaran, saluran pemasaran dianalisis secara deskriptif untuk mengetahui pola pemasaran ikan tongkol di Desa Seraya Timur. Saluran pemasaran ditelusuri dari tingkat produsen sampai pedagang pengumpul dan pedagang pengecer (pedagang perantara). Saluran pemasaran tersebut digunakan sebagai dasar dalam menggambarkan pola saluran pemasaran Ikan Tongkol di Desa Seraya Timur, sedangkan marjin pemasaran dan farmer share dianalisis secara kuantitatif untuk mengetahui efisiensi pemasaran data akan dianalisis berdasarkan rumus sebagai berikut.

$\mathrm{M}=\mathrm{Hk}-\mathrm{Hp}$

(Daniel, 2002)

Keterangan:

$\mathrm{M} \quad=$ Marjin Pemasaran

$\mathrm{Hk}=$ Harga Konsumen

$\mathrm{Hp}=$ Harga Produsen

Untuk menghitung presentase marjin, digunakan rumus dari Hanafiah dan Saefuddin (2010) sebagai berikut. 
p-ISSN : 2599-1418

e-ISSN : 2599-1426

$\% \mathrm{M}=\frac{M}{H} \times 100$

(2)

(Hanafiah dan Saefuddin, 2010)

Keterangan:

$\% \mathrm{M}=$ Presentase Marjin

$\mathrm{HE}=$ Harga Eceran

$\mathrm{M} \quad=$ Marjin

Untuk menghitung farmer share, digunakan rumus dari Utami Dewi (2006) sebagai berikut.

$\mathrm{Fs}=\frac{p}{p} X 100 \%$

(3)

(Utami Dewi 2006)

Keterangan:

$\begin{array}{ll}\text { Fs } & \text { Presentase harga yang } \\ & \text { diterima nelayan } \\ \mathrm{Pf} & =\text { harga ikan ditingkat nelayan } \\ \mathrm{Pr} & =\text { harga ikan ditingkat pengecer }\end{array}$

Untuk mengetahui tingkat efisiensi pemasaran ikan pada masing-masing lembaga pemasaran digunakan rumus dari Soekartawi (2002) sebagai berikut.

Eps $=\frac{B}{H} X 100$

(4)

(Soekartawi, 2002)

Keterangan:

Eps = Efisiensi pemasaran

$\mathrm{Bp}=$ Biaya Pemasaran

$\mathrm{HE}=$ Harga Eceran

Kriteria: - Eps $<5 \%$ Efisien

- Eps $>5 \%$ Tidak Efisien

Dalam analisis marjin pemasaran dan farmer Share hanya dilakukan perbandingan antara saluran pemasaran yang satu dengan saluran pemasaran yang lain. Saluran pemasaran yang memiliki marjin pemasaran terkecil dan farmer Share terbesar adalah saluran pemasaran yang paling efisien, dan saluran pemasaran yang memiliki marjin pemasaran terbesar dan farmer share adalah saluran pemasaran yang kurang efisien.

\section{HASIL DAN PEMBAHASAN Hasil}

Pola saluran pemasaran ikan tongkol hasil tangkapan nelayan di Desa Seraya timur yaitu, pertama nelayan ke pedagang pengecer kemudian konsumen, kedua nelayan ke pedagang pengumpul ke pedagang pengecer kemudian ke konsumen, ketiga nelayan ke pedagang pengumpul
Jurnal Pendidikan Ekonomi Undiksha

Volume 10 No. 2 Tahun 2018

kemudian ke pedagang besar (luar daerah). Saluran I merupakan salah satu saluran pemasaran yang digunakan oleh nelayan. Ketika nelayan memperoleh hasil tangkapan dalam jumlah banyak, biasanya pedagang pengecer langsung mendatangi para nelayan dan langsung menjual ikan ke pedagang pengecer dalam jumlah yang banyak $>100$ $\mathrm{kg}$ ) sedangkan pedagang pengecer hanya mampu membeli dalam jumlah sedikit $(<50$ $\mathrm{kg}$ ) sehingga jika dijual ke pedagang pengecer, jumlah tersebut tidak dapat terjual semuanya. Nelayan menggunakan saluran ini jika ikan yang dihasilkan sedikit atau jika sangat mengenal pedagang pengecer tesebut. Pola saluran II merupakan saluran pemasaran yang banyak digunakan oleh nelayan. Nelayan yang memperoleh Ikan Tongkol, langsung diambil oleh pedagang pengumpul kemudian menjual kepada pedagang pengecer, pedagang pengumpul jarang menjual langsung kepada konsumen akhir. Pola saluran III yang menjadi konsumen akhir Ikan Tongkol yang diperoleh nelayan adalah konsumen yang ada di luar daerah. Biasanya pedagang pengumpul mendapat pesanan dari pelanggannya untuk mengirimkan Ikan Tongkol dalam jumlah banyak minimal 1 ton. Dalam hal ini, harga Ikan Tongkol sangat ditentukan oleh jumlah persediaan yang ada di pedagang pengumpul, jika persediaannya masih mencukupi maka harga yang ditawarkan kepada nelayan rendah, namun jika persediaannya sedikit untuk memenuhi pesanan maka saat itu juga harga yang ditawarkan kepada nelayan juga tinggi. Marjin pemasaran merupakan selisih antara harga beli konsumen dengan harga jual produsen.

Marjin pemasaran ini merupakan salah satu cara untuk melihat apakah saluran pemasaran tersebut efisien atau tidak. Semakin panjang tataniaga (semakin banyak lembaga yang terlibat) maka semakin besar marjin tataniaga (Daniel, 2002). Apabila semakin besar marjin pemasaran, akan menyebabkan harga yang diterima produsen menjadi semakin kecil dan semakin mengindikasikan sebagai sistem pemasara yang tidak efisien. Marjin pemasaran untuk masing-masing saluran pemasaran lkan Tongkol hasil tangkapan nelayan di Desa Seraya Timur Tahun 2017 sebagai berikut pada tabel 2. 
Tabel 2. Marjin Pemasaran dan Persentase Marjin pada masing-masing saluran pemasaran ikan tongkol hasil tangkapan nelayan di Desa Seraya Timur Tahun 2017.

\begin{tabular}{cr}
\hline Saluran Pemasaran & Marjin P \\
II & \\
III & \\
Farmer Share adalah persentase \\
jual nelayan (produsen) terhadap \\
ditingkat pedagang pengecer atau \\
yang dibayar konsumen terakhir. \\
asaran dikatakan efisien apabila \\
asaran yang memiliki nilai farmer
\end{tabular}

Pemasaran

(rp/kq)

5.000

11.000

8.000
Persentase Marjin

$25,00 \%$

$44,00 \%$

$34,78 \%$ harga jual nelayan (produsen) terhadap

harga ditingkat pedagang pengecer atau

harga yang dibayar konsumen terakhir.

Pemasaran dikatakan efisien apabila

pemasaran yang memiliki nilai farmer share (bagian harga) yang besar. Untuk mengetahui besarnya bagian harga yang diterima nelayan pada masing-masing pola saluran pemasaran ikan tongkol di Desa Seraya Timur dapat dilihat pada tabel 3 berikut ini.

Tabel 3. Farmer Share yang diterima nelayan pada hasil tangkapan ikan tongkol di Desa Seraya Timur tahun 2017

\begin{tabular}{cc}
\hline Saluran Pemasaran & Farmer Share \\
I & $75,00 \%$ \\
II & $57,69 \%$ \\
III & $65,21 \%$
\end{tabular}

Efisiensi saluran pemasaran ikan tongkol hasil tangkapan nelayan di Desa Seraya Timur pada masing-masing lembaga pemasaran yaitu pola saluran I dari nelayan ke pedagang pengecer kemudian konsumen, kedua dari nelayan ke pedagang pengumpul ke pedagang pengecer kemudian ke konsumen dan pola saluran ketiga dari nelayan ke pedagang pengumpul kemudian ke pedagang besar (luar daerah). Saluran pemasaran ikan tongkol di Desa Seraya timur tergolong panjang. karena untuk sampai ke tangan konsumen harus melewati pedagang pengecer, pedagang pengumpul dan pedagang antar luar daerah. Ikan tongkol merupakan salah satu makanan pokok yang mudah rusak, sehingga jika saluran pemasaran panjang akan dapat mengurangi kualitas dari ikan tongkol itu sendiri. Panjangnya saluran pemasaran yang dilalui menyebabkan saluran pemasaran menjadi kurang efisien, karena selain kualitas ikan yang menurun, marjin pemasaran akan semakin besar dan bagian harga yang diterima nelayan akan semakin kecil. Dalam rumus Soekartawi (2002), kriteria untuk dapat dikatakan efisien adalah $<5 \%$ dan tidak efisien $>5 \%$. Untuk mengetahui tingkat efisiensi saluran pemasaran ikan tongkol pada masing-masing lembaga pemasaran di Desa Seraya Timur dapat dilihat sebagai berikut pada tabel 4 .

Tabel 4. Tingkat efisiensi saluran pemasaran ikan tongkol hasil tangkapan nelayan pada masingmasing lembaga pemasaran di Desa Seraya Timur Tahun 2017.

\begin{tabular}{lcccc}
\hline & \multicolumn{3}{c}{ Efisiensi Pemasaran } & \\
Lempaga remasaran & Saluran & Saluran & Saluran & Keterangan \\
& I & II & III & \\
Pedagang Pengumpul & - & $6,53 \%$ & $9,56 \%$ & Tidak Efisien \\
Pedagang Pengecer & $2,50 \%$ & $1,92 \%$ & - & I \& II (Efisien) \\
\hline
\end{tabular}

Berdasarkan tabel 4, terlihat bahwa secara keseluruhan efisiensi pemasaran pada masing-masing lembaga pemasaran ikan tongkol di Desa Seraya Timur Tahun 
2017 menyatakan bahwa pola saluran I sudah efisien sedangkan pola saluran II dan III tidak efisien karena persentasenya lebih besar dari 5\%. Untuk pedagang pedagang pengumpul tidak efisien karena pola saluran II persentasenya $6,53 \%$ dan $1,92 \%$, sedangkan pada saluran III besarnya yaitu $9,56 \%$. Pada saluran I sudah efisien karena persentasenya sebesar $2,50 \%$. Jika dilihat secara keseluruhan dari ketiga saluran pemasaran yang ada, saluran I merupakan saluran yang paling efisien dengan tingkat persentase sebesar 2,50\% dibandingkan saluran lainnya.

\section{Pembahasan}

Pola saluran pemasaran ikan tongkol di Desa Seraya Timur yaitu pertama dari nelayan ke pedagang pengecer kemudian konsumen, pedagang pengecer biasanya membeli ikan tongkol di nelayan dengan harga lebih mahal dari harga pengumpul, namun saluran ini jarang digunakan oleh para nelayan di Desa Seraya Timur karena biasanya ikan tongkol yang diperoleh nelayan dengan jumlah yang banyak (>100 $\mathrm{kg}$ ), sedangkan pedagang pengecer lokal hanya dapat membeli ikan tongkol dengan jumlah yang lebih sedikit $(<50 \mathrm{~kg})$. Nelayan menggunakan pola ini, ikan tongkol yang dihasilkan tidak akan terjual seluruhnya. Pola ini akan digunakan nelayan jika ikan tongkol hasil tangkapannya sedikit $(<50 \mathrm{~kg})$ atau karena adanya kedekatan hubungan antara nelayan dengan pedagang pengecer.

Kedua dari nelayan ke pedagang pengumpul ke pedagang pengecer ke pedagang pengecer kemudian konsumen. Nelayan di Desa Seraya Timur pada umumnya menggunakan saluran II, karena selain dapat membeli ikan tongkol dengan jumlah banyak biasanya juga karena adanya kerja sama dalam hal permodalan dalam penangkapan ikan tongkol itu sendiri. Pedagang pengumpul biasanya menawarkan bantuan modal dalam bentuk bensin kepada nelayan yang memiliki modal kecil dengan jaminan dibayar setelah mendapatkan ikan dari hasil tangkapannya itu sendiri. Hal ini dilakukan pedagang pengumpul agar ada keterikatan antara nelayan dengan pedagang pengumpul, sehingga nelayan cenderung untuk menjual hasil tangkapannya kepada pedagang pengumpul.
Ketiga dari nelayan ke pedagang pengumpul kemudian pedagang besar (luar daerah), yang menjadi konsumen akhir dalam pola ini adalah konsumen yang ada diluar daerah. Nelayan hanya menjual ikan hasil tangkapannya kepada pedagang pengumpul dan nantinya pedagang pengumpul inilah yang akan menyalurkan ke konsumen yang ada di luar daerah melalui pelanggannya. Pedagang pengumpul akan menerima pesanan dari pedagang besar yang nantinya akan disalurkan kepada konsumen yang ada di luar daerah.

Marjin pemasaran merupakan selisih antara harga yang dibayarkan konsumen dengan harga yang diterima oleh produsen. Besar kecilnya jumlah marjin dalam suatu saluran pemasaran sangat ditentukan oleh panjang pendeknya saluran pemasaran dan aktivitas pemasaran yang dilaksanakan serta keuntungan yang diharapkan oleh lembaga pemasaran yang terlibat dalam proses pemasaran. Berdasarkan hasil penelitian mengenai analisis efisiensi saluran pemasaran ikan tongkol di Desa Seraya Timur yang telah dikemukakan di atas, maka dapat dilihat bahwa terdapat tiga pola saluran pemasaran. Adapun perhitungan marjin pemasaran untuk masing-masing saluran pemasaran yaitu sebagai berikut.

Pada saluran I, terlihat bahwa marjin pemasaran dapat yang terjadi antara nelayan dengan pengecer sebesar Rp.5.000,00/kg ikan tongkol. Saluran ini merupakan saluran pemasaran yang paling pendek karena hanya melalui satu pedagang perantara yaitu pedagang pengecer saja dan langsung ke konsumen sehingga jumlah marjin yang terjadi masih relatif kecil karena biaya yang dikeluarkan dalam pemasaran kecil yaitu sebesar Rp.500,00/kg ikan tongkol.

Pada saluran II terlihat bahwa marjin yang terjadi antara nelayan dengan pedagang pengumpul ke pedagang pengecer kemudian konsumen sebesar Rp.11.000,00/kg ikan tongkol. Saluran pemasaran pada pola II tergolong panjang karena untuk sampai di tangan konsumen harus melewati pedagang pengumpul dan pedagang pengecer sehingga jumlah biaya yang dikeluarkan besar yaitu Rp.1.700,00/kg ikan tongkol.)

Pola saluran pemasaran III, yang menjadi konsumen akhir dari ikan tongkol hasil tangkapan nelayan di Desa Seraya 
p-ISSN : 2599-1418

e-ISSN : 2599-1426

Timur adalah konsumen diluar daerah, namun penelitian ini hanya dilakukan sampai di pedagang pengumpul dengan jumlah marjin sebesar Rp.8.000,00/kg ikan tongkol, saluran pemasaran pola III tergolong panjang karena jarak antara produsen dengan konsumen sangat jauh sehingga untuk sampai tangan konsumen harus melalui beberapa pedagang perantara dan memerlukan waktu yang cukup lama sehingga jumlah biaya yang dikeluarkan cukup besar yaitu Rp. 2.200,00/kg ikan tongkol. Farmer Share merupakan bagian dari harga dibayarkan oleh konsumen yang dapat dinikmati oleh produsen. Tataniaga dapat dikatakan semakin efisien jika semakin kecil marjin pemasaran dan semakin tinggi bagian harga yang diterima nelayan. Berdasarkan hasil penelitian yang telah dikemukakan di atas, maka Farmer Share dari masing-masing saluran pemasaran yaitu, pola saluran pemasaran I memilki saluran pemasaran yang pendek sehingga mengakibatkan bagian harga yang diterima nelayan (farmer share) cukup besar yaitu sebesar $75,00 \%$, pola saluran pemasaran II memiliki saluran panjang, panjangnya saluran pemasaran menyebabkan bagian harga yang diterima nelayan menjadi lebih kecil yaitu sebesar $57,69 \%$ dan pola saluran III dikatakan panjang karena jarak antara produsen dengan konsumen yang sangat jauh sehingga untuk sampai tangan konsumen harus melalui beberapa pedagang perantara. Dalam penelitian ini hanya dilakukan sampai pedagang pengumpul karena keterbatasan waktu, biaya dan tenaga, sehingga bagian harga yang diterima nelayan hanya sebesar $65,21 \%$.

Berdasarkan pembahasan di atas dapat diketahui bahwa jumlah marjinnya cukup besar pada saluran I sebesar Rp.5.000,00/kg dan pada saluran II sebesar Rp.11.000,00/kg sedangkan pada saluran III jumlah marjinnya Rp.8.000,00/kg. Untuk bagian harga yang diterima nelayan pada saluran I sebesar $75,00 \%$, pada saluran II sebesar $57,69 \%$ dan pada saluran III sebesar $65,21 \%$. Dari ketiga pola saluran pemasaran tersebut, saluran pemasaran I marjin pemasarannya lebih sedikit dari pada saluran lainnya karena merupakan saluran yang paling pendek. Hal ini sesuai dengan pendapat Daniel (2002), bahwa semakin panjang tataniaga (semakin banyak lembaga
Jurnal Pendidikan Ekonomi Undiksha

Volume 10 No. 2 Tahun 2018

pemasaran yang terlibat) maka marjin pemasaran akan semakin besar. Semakin besar jumlah marjin pemasaran ini akan menyebabkan harga yang diterima produsen menjadi semakin kecil dan semakin mengindikasikan saluran tersebut semakin tidak efisien.

Tingkat efisiensi pada masing-masing lembaga pemasaran, secara keseluruhan yaitu, pada saluran I sebesar 2,50\%, pada saluran II sebesar $6,51 \%$ dan 1,92\%, pada saluran III sebesar $9,56 \%$. Dalam rumus Soekartawi (2002) kriteria untuk dapat dikatakan efisien adalah $<5 \%$ dan tidak efisien adalah $>5 \%$. Dari ketiga saluran yang ada, efisiensi hanya terjadi pada saluran I dengan persentase sebesar $2,50 \%$. Dilihat secara keseluran dari tiga saluran tersebut, saluran I lebih efisien dari saluran lainnya karena persentasenya paling sedikit. Hal ini menunjukan bahwa saluran pendek (saluran I) lebih efisien dari saluran panjang.

Berdasarkan pendapat Daniel (2002), bahwa pola saluran pemasaran Ikan Tongkol di Desa Seraya Timur belum efisien karena saluran pemasaran yang panjang. Dalam proses saluran pemasaran ikan tongkol di Desa Seraya Timur harus melewati beberapa pedagang perantara untuk sampai ke tangan konsumen akhir. Panjangnya saluran pemasaran selain mengeluarkan biaya yang lebih besar juga akan mengurangi kualitas dari ikan tongkol itu sendiri, sehingga semakin memperbesar perbedaan antara harga produsen dengan harga konsumen. Menurut Mubyarto (2002), pemasaran dikatakan efisien apabila memenuhi dua syarat yaitu mampu menyampaikan hasil kepada konsumen dengan biaya murah dan mampu mengadakan pembagian yang adil dari keseluruhan harga yang dibayar konsumen terakhir pada pihak yang ikut dalam kegiatan produksi dan tataniaga barang itu.

Dari pembahasan di atas dapat dilihat bahwa pemasaran ikan tongkol di Desa Seraya Timur belum efisien karena panjangnya saluran pemasaran yang dilalui sehingga biaya pemasaran menjadi lebih besar dan juga belum mampu mengadakan pembagian secara adil diantara pihak-pihak yang terlibat dalam pemasaran karena terlihat bahwa nelayan mendapat bagian harga jauh lebih kecil dibandingkan pedagang pengumpul dan pedagang 
pengecer yang mengeluarkan biaya sedikit namun mendapat keuntungan lebih besar.

Dampak positif yang diterima oleh nelayan jika saluran tersebut efisien maka akan memberi keuntungan yang baik bagi nelayan, sehingga nelayan berhasil dalam kegiatan pemasarannya. Sebaliknya, jika saluran pemasaran yang terjadi tidak efisien, misalnya saluran pemasarannya terlalu panjang maka nelayan akan menjadi pihak yang dirugikan. Sedangkan di Desa Seraya Timur berdasarkan observasi dan wawancara yang telah dilakukan nelayan di Desa Seraya Timur masih cenderung menggunakan saluran pemasaran II dan III yang tidak efisien. Hal ini menyebabkan dampak yang negatif bagi nelayan di Desa Seraya Timur, yaitu keuntungan yang diperoleh sedikit, harga jual ikan tongkol murah, dan kadang-kadang ikan tongkol tidak sepenuhnya dibayar oleh pedagang perantara. Kerugian ini terjadi karena saluran pemasarannya terlalu panjang dan proses pemasarannya nelayan harus melewati pedagang pengumpul, pedagang pengecer baru sampai ke tangan konsumen.

\section{PENUTUP \\ Simpulan}

Berdasarkan hasil penelitian dan pembahasan yang telah dibuat, dapat disimpulkan beberapa hal sebagai berikut. Terdapat tiga Pola saluran pemasaran ikan tongkol hasil tangkapan nelayan di Desa Seraya timur. Pola saluran pertama yaitu dari nelayan ke pedagang pengecer kemudian konsumen, pola saluran kedua dari nelayan ke pedagang pengumpul ke pedagang pengecer kemudian konsumen, dan pola saluran ketiga yaitu dari nelayan ke pedagang pengumpul kemudian pedagang besar (luar daerah).

Berdasarkan perhitungan marjin pemasaran dan farmer share terhadap tiga pola saluran tersebut, saluran I memiliki jumlah marjin Rp 5.000/kg dan farmer share sebesar $75,00 \%$, saluran II memiliki jumlah marjin sebesar $\mathrm{Rp} 11.000 \mathrm{~kg}$ dan farmer share sebesar $57,69 \%$, saluran III memiliki jumlah marjin sebesar $\mathrm{Rp} 8.000 / \mathrm{kg}$ dan farmer share sebesar 65,21\%. Dari ketiga pola saluran pemasaran ikan tongkol hasil tangkapan nelayan di Desa Seraya Timur, pola saluran pemasaran yang paling efisien adalah pola saluran I karena merupakan pola saluran pemasaran paling yang pendek serta memiliki jumlah marjin yangpaling kecil dan farmer share paling besar yaitu Rp 5.000/kg dan $75,00 \%$ dari pola saluran pemasaran lainnya.

\section{Saran}

Berdasarkan simpulan hasil penelitian dan pembahasan tersebut, maka dalam penelitian ini dapat dikemukakan saran yaitu dalam pengembangan ikan tongkol hasil tangkapan nelayan di Desa Seraya Timur, diharapkan dapat dibangun sistem pemasaran yang efisien sehingga tidak merugikan nelayan. Dalam hal pemasaran ikan tongkol ini, yaitu dengan cara mengoptimalkan kembali peran dari kelompok nelayan yang selama ini belum dikembangkan secara maksimal. Sebaiknya ada kontrol yang dilakukan oleh perwakilan kelompok nelayan masing-masing dusun di Desa Seraya Timur agar tataniaga yang terlaksana tidak memberatkan nelayan maupun konsumen, berguna untuk menentukan harga jual ikan tongkol kepada pelaku tataniaga selanjutnya. Untuk memperkecil marjin pemasaran ikan tongkol maka salah satu upaya yang perlu diterapkan adalah membangun atau menghidupkan kembali kelompok nelayan selaku produsen dan juga sentralisasi lembaga pemasaran ditingkat desa dengan aturan main yang jelas dan disepakati oleh anggotanya. Dengan demikian maka nelayan akan memiliki posisi tawar yang lebih baik. Selain itu, dengan adanya sentralisasi lembaga pemasaran ditingkat desa, akan memudahkan nelayan apabila ada pihak swasta yang ingin menerapkan pola kemitraan/kerja sama dalam pemasaran ikan tongkol, sehingga kualitas produk dapat dijaga dan untuk menghindari jatuhnya harga pada saat ikan tongkol banyak maka perlu adanya pengelolaan ikan tongkol menjadi beberapa produk olahan yang dapat meningkatkan nilai tambah bagi nelayan, sehingga mereka tidak hanya menjualnya dalam bentuk segar tetapi juga yang sudah terolah seperti abon, krupuk ikan dan lainlain. Untuk menerapkan itu semua, maka dukungan semua pihak yang terkait dengan pemasaran ikan tongkol sangat mutlak diharapkan baik pemerintah daerah maupun stakeholder lainnya. 


\section{DAFTAR PUSTAKA}

Amirullah, dan Haris Budiyono. 2005. Pengantar Manajemen. Yogyakarta: Graha IImu.

Daniel, Moehar. 2002. Pengantar Ekonomi Pertanian. Cetakan Pertama. Jakarta: Bumi Aksara.

Dewi, Utami. 2006. Analisis Kelayakan Usaha Tani dan Efisiensi Pemasaran Salak Pondoh (Kasus di Kecamatan Madukara, Kabupaten Banjarnegara, Propinsi Jawa Tengah). Skripsi (tidak diterbitkan). Program Studi Manajemen, Fakultas Pertanian, Institut Pertanian Bogor.

Gilarso, T. 2009. Pengantar IImu Ekonomi Bagian Mikro. Jilid 2. Jakarta: Penerbit Kanisinus.

Gitosudarmo, Indriyo. 2008. Manajemen Pemasaran. Edisi Pertama. Cetakan Keempat. Yogyakarta: BPFE.

Hanafiah, dan Saefuddin. 2010. Tataniaga Hasil Perikanan. Jakarta: Universitas Indonesia.

Kotler, Philip dan Gary Amstrong. 2001. Prinsip-prinsip Pemasaran. Jilid 2. Edisi Kedelapan. Terjemahan Damos Sihombing. Principles of Marketing, $8^{\text {th }}$ Edition. 2001. Jakarta: Erlangga.

Manullang, M. 2005. Pengantar Ekonomi Perusahaan. Yogyakarta: Liberty

Mubyarto. 2002. Pengantar Ekonomi Pertanian. Edisi Ketiga. Jakarta: PT. Pustaka LP3ES.

Soekartawi. 2002. Panduan Membuat Usaha Proyek Pertanian dan Pedesaan. Yogyakarta: ANDI.

Sukardi. 2008. Metodelogi penelitian pendidikan. Cetakan Keenam. Yogyakarta: PT Bumi Aksara.

Swastha, Basu. 2002. Azas-Azas Marketing. Edisi Ketiga. Yogyakarta: Liberty. 